\title{
IMPLEMENTASI STRATEGI MEMBANGUN HUBUNGAN BAIK PADA PERUSAHAAN JASA KONSTRUKSI
}

\author{
Ajeng Yuanitasari, ${ }^{1)}$; Paulus Wardoyo ${ }^{2}$; Indarto \\ ajengyuanitasari29@gmail.com ${ }^{1)}$; paulusww@usm.ac.id ${ }^{2}$; indarto@usm.ac.id id $^{3)}$ \\ Magister Management, Universitas Semarang, Semarang, Indonesia
}

\section{Info Artikel}

Sejarah Artikel:

Diterima : Juli 2019

Disetujui : Agustus 2019

Dipublikasikan: Agustus

2019

Keywords:

Business strategy;

Construction service;

Customer Relationship

Management (CRM);

Service quality;

Customer satisfaction.

\begin{abstract}
Abstrak
Hubungan relasi antara penyedia jasa konstruksi dengan pelanggannya memperngaruhi kelangsungan bisnis penyedia jasa konstruksi. Adanya perubahan kondisi lingkungan eksternal perusahaan penyedia jasa konstruksi saat ini, harus disikapi dengan menerapkan strategi untuk tetap bertahan. Tujuan yang hendak dicapai dalam penelitian ini adalah untuk mengalisis strategi membangun hubungan baik perusahaan jasa konstruksi terhadap pelanggannya untuk terus mendapatkan proyek konstruksi. Metode penelitian yang digunakan dalam penilitian ini yaitu menggunakan pendekatan fenomenologi kualitatif. Hasil penelitian ini adalah: strategi untuk membangun hubungan baik antara perusahaan jasa konstruksi dengan pelanggannya yaitu dengan menggunakan strategi customer relationship management (CRM) dengan menerapkan komponen proses, manusia dan teknologi. Memberikan pelayanan yang berkualitas untuk pelanggannya sehingga meningkatkan nilai kepuasan pelanggan pada kualitas pelayanan dan kualitas produk.
\end{abstract}

IMPLEMENTATION OF STRATEGY FOR BUILDING GOOD RELATIONS ON CONSTRUCTION SERVICE COMPANIES

\begin{tabular}{|c|c|}
\hline & Abstract \\
\hline & $\begin{array}{l}\text { Relationships between construction service providers and their customers affect the } \\
\text { business continuity of construction service providers. Changes in the current external environment } \\
\text { of construction service providers must be addressed by implementing strategies to stay afloat. The } \\
\text { objective to be achieved in this research is to analyze the strategy of building good relations between } \\
\text { construction service companies and their customers to continue to get construction projects. The } \\
\text { research method used in this research is to use a qualitative phenomenological approach. The } \\
\text { results of this study are: a strategy to build good relations between construction service companies } \\
\text { and their customers by using a customer relationship management (CRM) strategy by applying } \\
\text { process, human and technology components. Providing quality services for its customers thereby } \\
\text { increasing the value of customer satisfaction on service quality and product quality. }\end{array}$ \\
\hline${ }^{\square}$ Alamat korespondensi : J & $\begin{array}{lll}\text { Soekarno-Hatta Semarang } & \text { ISSN }\end{array}$ \\
\hline E-mail: ajengyuanitasari & $\begin{array}{r}1979-4800 \text { (cetak) } \\
2580-8451 \text { (online) }\end{array}$ \\
\hline
\end{tabular}




\section{PENDAHULUAN}

Pembangunan nasional merupakan suatu bagian yang tidak dapat terpisahkan dari proses pembangunan daerah. Tujuan dari pembangunan nasional pun sangat jelas, yaitu untuk meningkatkan derajat dan harkat serta martabat, kualitas daerah agar dapat bersaing dalam era globalisasi. Pihak-pihak yang terkait dalam pembangunan yaitu pengguna jasa dan penyedia jasa. Pengguna jasa adalah orang perseorangan atau badan sebagai pemberi tugas atau pemilik pekerjaan/proyek yang memerlukan layanan jasa konstruksi. Pengguna jasa harus memiliki kemampuan membayar biaya pekerjaan konstruksi yang didukung dengan dokumen pembuktian dari lembaga perbankan dan atau lembaga keuangan bukan bank. Jika pengguna jasa adalah Pemerintah, pembuktian kemampuan untuk membayar diwujudkan dalam dokumen tentang ketersediaan anggaran.

Pemilihan penyedia jasa konstruksi yang diatur dalam Peraturan Presiden No 54 tahun 2010 salah satunya dilakukan dengan cara Penunjukan Langsung. Sistem Penunjukan langsung oleh Pejabat Pengadaan kepada penyedia jasa konstruksi dengan menilai kemampuan melaksanakan pekerjaan dan/atau memenuhi kualifikasi, melihat pengalaman-pengalaman pekerjaan konstruksi yang telah dikerjakan dan track record kinerja dari penyedia jasa konstruksi tersebut. Komunikasi dan relationship dengan Pejabat Pengadaan menjadi salah satu strategi yang harus dilakukan oleh penyedia jasa konstruksi. Perusahaan yang mampu untuk menjalin relationship jangka panjang dengan pelangganya adalah perusahaan yang sukses.

CV. Dwi Cahya Perkasa adalah perusahaan yang bergerak pada bidang penyedia jasa konstruksi di Kota Semarang yang mengerjakan proyek-proyek pembangunan dari Pemerintah Kota Semarang. CV. Dwi Cahya Perkasa telah berdiri sejak tahun 2012 dan masih eksis di pembangunan Kota Semarang sampai saat ini.

Tabel 1 Daftar Pekerjaan CV. Dwi Cahya Perkasa (tahun 2013-2018)

\begin{tabular}{|l|c|c|c|c|c|c|}
\hline \multicolumn{1}{|c|}{ TAHUN } & 2013 & 2014 & 2015 & 2016 & 2017 & 2018 \\
\hline $\begin{array}{l}\text { Jumlah Proyek } \\
\text { Per Tahun }\end{array}$ & 31 & 17 & 22 & 14 & 9 & 5 \\
\hline $\begin{array}{l}\text { Omset Per } \\
\text { Tahun } \\
\text { (rupiah) }\end{array}$ & 1.177 .353 .636 & 1.148 .798 .182 & 1.312 .685 .450 & 1.547 .642 .897 & 1.171 .056 .485 & 986.370 .025 \\
\hline $\begin{array}{l}\text { Pertumbuhan } \\
(\%)\end{array}$ & $0 \%$ & $-2 \%$ & $14 \%$ & $18 \%$ & $-24 \%$ & $-16 \%$ \\
\hline
\end{tabular}

Sumber : Data diolah tahun 2018

Melihat data di atas, cv. dwi cahya perkasa dalam 6 tahun terakhir mengalami fluktuasi dalam bisnisnya. Pada 2 tahun terakhir cv. dwi cahya perkasa mengalami penurunan yang sangat signifikan dibandingkan tahun-tahun sebelumnya. penurunan jumlah proyek pembangunan yang dikerjakan sangat mempengaruhi jumlah omset yang didapat juga. CV. Dwi Cahya Perkasa mengerjakan proyek pembangunan melalui sistem penunjukan langsung oleh Pejabat Pengadaan di L/K/D/I Kota Semarang. Tahun 2017 hanya 7 (tujuh) instansi Pemerintah yang memberikan proyek pembangunan kepada CV. Dwi Cahya Perkasa, kemudian di tahun 2018 menurun lagi menjadi hanya 5 (lima) instansi Pemerintah saja. 
Setiap perusahaan berusaha menanggulangi terjadinya perubahan dalam bisnis yang dijalaninya. Perubahan dapat dilakukan dengan menerapkan strategi customer relationship management pada perusahaan tersebut. Dengan diterapkannya strategi tersebut, perusahaan akan mendapatkan keunggulan kompetitif. Keunggulan kompetitif dapat dijadikan alat untuk menanggulangi persaingan dengan perusahaan lainnya dalam mencapai target bisnis. Pada umumnya, target yang ditetapkan oleh perusahaan adalah memaksimalkan proses bisnis yang ada baik dari segi peningkatan penjualan produk maupun peningkatan relasi dengan pelanggan. (Darudiato, Novianto, Hendra, Reynaldo, \& Selvi, 2011)

Dalam perspektif manajemen pemasaran strategik permasalahan tersebut dapat diatasi dengan penerapan customer relationship management (CRM) karena strategi ini berkorelasi dengan penciptaan kepuasan, penciptaan keunggulan bersaing, peningkatan kualitas pelayanan dan hubungan jangka panjang yang saling menguntungkan antara perusahaaan dengan pelanggan (Chadiq, 2015). menurut Schiffman (2004) dalam (Chadiq, 2015) menekankan bahwa CRM adalah cara perusahaan dalam membina relasi dengan para pelanggan dengan tujuan memelihara kesetiaan dan komitmen pelanggan untuk tetap menggunakan produk perusahaan yang bersangkutan.

Pengertian CRM menurut (Ishak, 2006) dalam (Wildyaksanjani \& Sugiana, 2018a) adalah manajemen hubungan pelanggan yaitu suatu jenis manajemen yang secara khusus membahas teori mengenai penanganan hubungan antara perusahaan dengan pelanggannya dengan tujuan meningkatkan nilai perusahaan di mata pelanggannya. Sistem penunjukan langsung pada proyek pembangunan di Kota Semarang sangat erat hubungannya antara Pejabat pengadaan dengan penyedia jasa konstruksi. Banyaknya penyedia jasa konstruksi di Kota Semarang juga membuat persaingan yang ketat untuk mendapatkan proyek pembangunan. Jumlah penyedia jasa konstruksi lebih banyak dibandingkan dengan jumlah proyek pembangunan yang tersedia di suatu instansi Pemerintah.

Pemerintah menginginkan pengadaan barang/jasa yang efisien, terbuka dan kompetisi yang sehat untuk ketersediaan barang/jasa yang terjangkau dan berkualitas, sehingga akan berdampak pada peningkatan pelayanan publik. Namun penyedian barang/jasa dengan menggunakan sistem penunjukan langsung ini lebih mengutamakan hubungan baik dan kedekatan antara pejabat pengadaan dengan penyedia jasa konstruksi. Maka yang menjadi rumusan masalah pada penelitian ini adalah "Bagaimana strategi membangun hubungan baik dengan pengguna jasa konstruksi yang dilakukan oleh CV. Dwi Cahya Perkasa untuk mendapatkan proyek konstruksi”

\section{TELAAH PUSTAKA \\ Customer Relationship Management (CRM)}

Menururt Brown (2000:8) dan Rigby, Reichheld, Dawson (2003) dalam (Munandar, 2006) mengungkapkan bahwa CRM merupakan suatu proses mendapatkan, mempertahankan, dan mengembangkan pelanggan yang menguntungkan. Menurut (Lukas, 2001) keberhasilan CRM ditentukan oleh tiga faktor utama yaitu, manusia, proses dan teknologi untuk mengoptimalkan hubungan organisasi dengan semua tipe pelanggan. 


\section{Kualitas Pelayanan}

Menurut penelitian Sabihaini (2002) dalam (Rizan \& Arrasyid, 2008) yang menyimpulkan bahwa peningkatan kualitas pelayanan akan memberikan dampak yang baik untuk meningkatkan loyalitas. Kualitas pelayanan memiliki pengaruh langsung terhadap loyalitas dan mempengaruhi loyalitas melalui kepuasan. Tjiptono dalam (Kalalo, 2013) menyatakan terdapat lima dimensi dalam kualitas layanan meliputi: Kepercayaan, daya tanggap, jaminan, empati, bukti fisik.

\section{Kepuasan Pelanggan}

Kepuasan pelanggan akan timbul jika kebutuhan dan keinginan pelanggan dapat terpenuhi oleh produk yang berkualitas. Menurut Irawan dalam (Aditia, 2012) tingkat kepuasan konsumen dapat ditentukan berdasarkan pada 5 faktor utama yang harus diperhatikan oleh sebuah perusahaan, yaitu : Kualitas produk, kualitas pelayanan, emosional, harga, biaya dan kemudahan.

\section{METODE}

Penelitian tentang strategi membangun hubungan baik dengan pengguna jasa konstruksi yang dilakukan oleh CV. Dwi Cahya Perkasa yang akan di lakukan oleh penulis menggunakan pendekatan kualitatif. Fokus penelitian pada penelitian fenomenologi ini fokus pada customer relationship management CV. Dwi Cahya Perkasa sebagai perusahaan jasa konstruksi memperoleh proyek konstruksi dengan sistem penunjukan langsung di Kota Semarang. Menggunakan teknik pengumpulan data berupa wawancara, obervasi dan dokumentasi.

\section{HASIL DAN PEMBAHASAN}

Tabel 2 Hasil Wawancara

\begin{tabular}{|c|c|c|c|c|}
\hline KOMPONEN & OWNER & SKPD & PESAING & $\begin{array}{l}\text { POLA DAN } \\
\text { KONSEP }\end{array}$ \\
\hline $\begin{array}{c}\text { CUSTOMER } \\
\text { RELATIONSH } \\
\text { IP } \\
\text { MANAGEME } \\
N T(\mathrm{CRM})\end{array}$ & 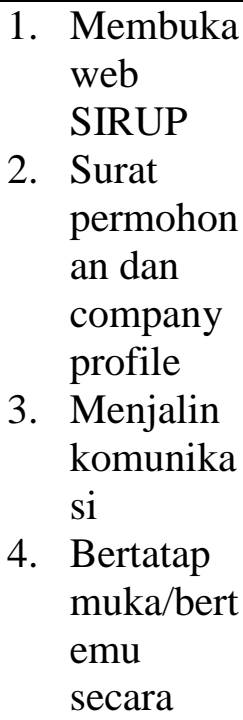 & 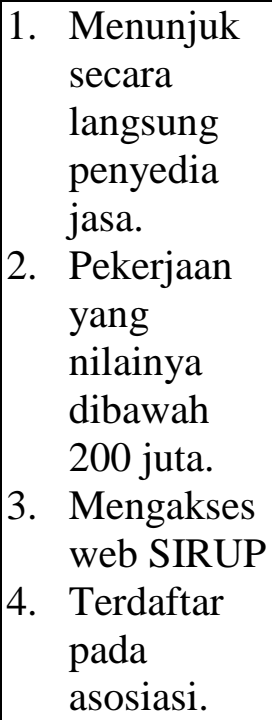 & 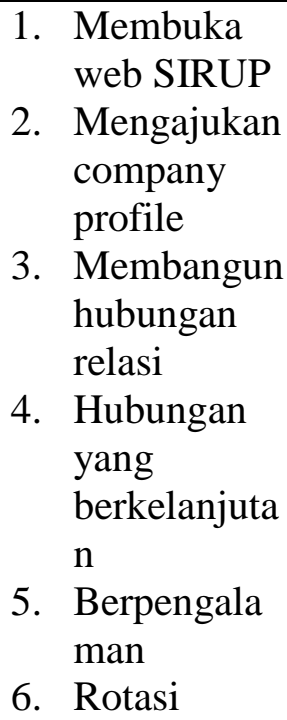 & 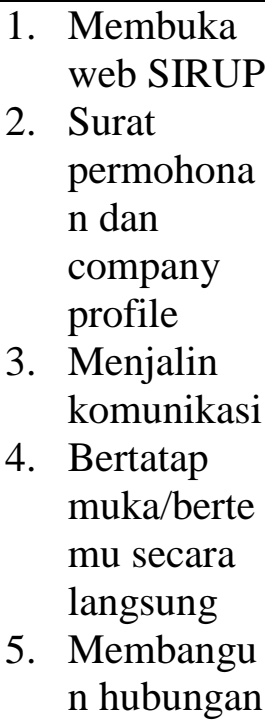 \\
\hline
\end{tabular}




\begin{tabular}{|c|c|c|c|c|}
\hline & $\begin{array}{l}\text { langsung } \\
\text { 5. Membang } \\
\text { un } \\
\text { hubungan } \\
\text { relasi } \\
\text { 6. SDM } \\
\text { yang } \\
\text { berkompe } \\
\text { ten } \\
\text { 7. } \begin{array}{l}\text { Sistem } \\
\text { kerja baik }\end{array} \\
\text { 8. } \begin{array}{l}\text { Peralatan } \\
\text { yang } \\
\text { memadai }\end{array} \\
\text { 9. Rotasi } \\
\text { jabatan }\end{array}$ & 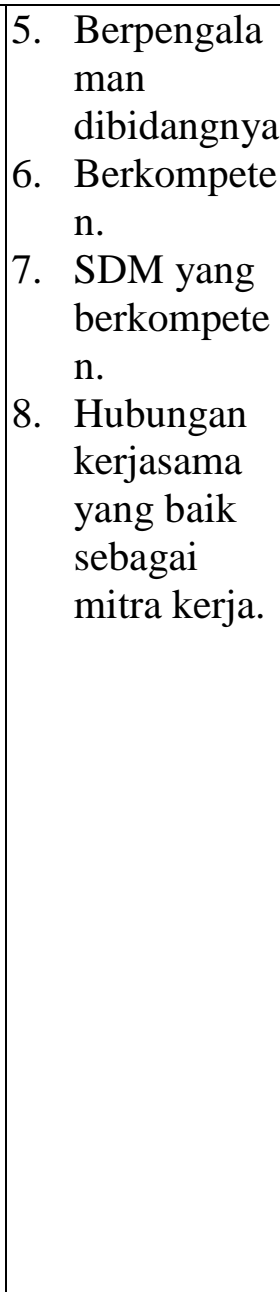 & $\begin{array}{l}\text { jabatan } \\
\text { 7. Persaingan }\end{array}$ & 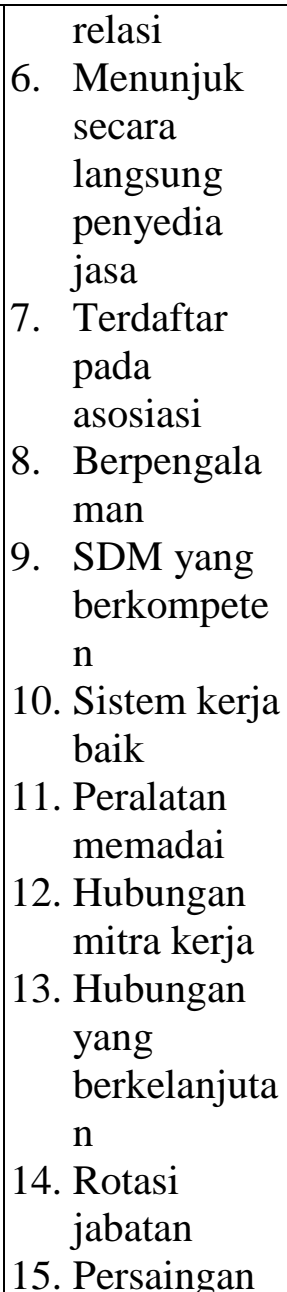 \\
\hline $\begin{array}{c}\text { KUALITAS } \\
\text { PELAYANA } \\
\mathrm{N}\end{array}$ & $\begin{array}{ll}\text { 1. } \begin{array}{l}\text { Bahan } \\
\text { berkualita } \\
\mathrm{s}\end{array} \\
\text { 2. Peralatan } \\
\text { yang } \\
\text { memadai } \\
\text { 3. Sesuai } \\
\text { kontrak } \\
\text { kerja } \\
\text { 4. Layanan } \\
\text { Prima } \\
\text { 5. Sesuai } \\
\text { kontrak } \\
\text { kerja } \\
\text { 6. Jaminan } \\
\text { pemelihar } \\
\text { aan }\end{array}$ & \begin{tabular}{|ll} 
1. & $\begin{array}{l}\text { Kualitas } \\
\text { pekerjaan } \\
\text { baik }\end{array}$ \\
2. & $\begin{array}{l}\text { Bertanggun } \\
\text { g jawab }\end{array}$ \\
3. & $\begin{array}{l}\text { Dianggap } \\
\text { mampu }\end{array}$ \\
4. & Kenal baik \\
5. & Sesuai \\
kontrak \\
kerja \\
6. & Jaminan \\
pemeliharaa \\
n
\end{tabular} & \begin{tabular}{|ll} 
1. & Bahan \\
berkualitas \\
2. & Menjaga \\
& kualitas \\
3. & Komunikasi \\
4. & Jaminan \\
& pemeliharaan
\end{tabular} & 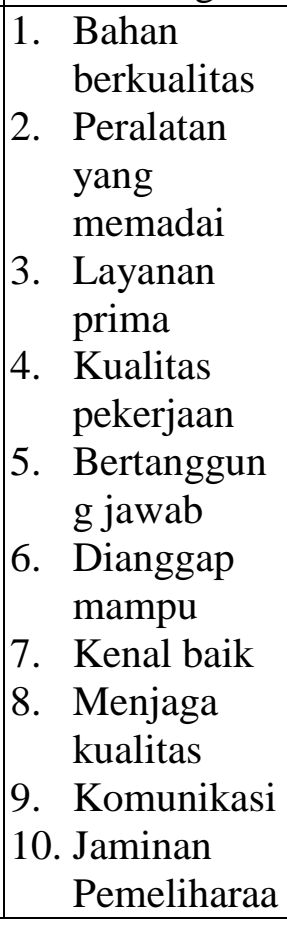 \\
\hline
\end{tabular}




\begin{tabular}{|c|c|c|c|c|}
\hline & & & & $\begin{array}{l}\mathrm{n} \\
\text { 11. Sesuai } \\
\text { kontrak } \\
\text { kerja }\end{array}$ \\
\hline $\begin{array}{c}\text { KEPUASAN } \\
\text { PELANGGA } \\
\mathrm{N}\end{array}$ & 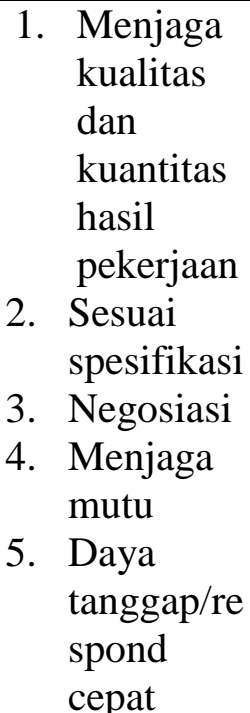 & $\begin{array}{ll}\text { 1. } & \text { Hasil } \\
\text { produk baik } \\
\text { 2. } & \text { Negosiasi } \\
\text { 3. } & \text { Sesuai } \\
\text { dengan } \\
\text { spesifikasi. } \\
\text { 4. } & \text { Selesai } \\
\text { tepat waktu }\end{array}$ & $\begin{array}{ll}\text { 1. } & \text { Negosiasi } \\
\text { 2. } & \text { Sesuai } \\
\text { spesifikasi }\end{array}$ & 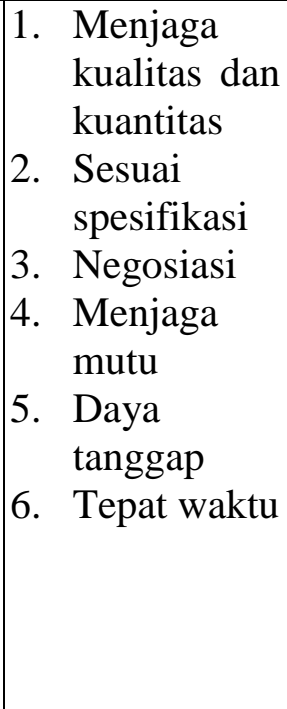 \\
\hline
\end{tabular}

\section{Prosedur Penunjukan Langsung Penyedia Jasa Konstruksi}

Dari pola hasil wawancara dengan pihak SKPD yang menjelaskan bahwa penunjukan langsung yaitu Penunjukan langsung adalah sistem memilih penyedia jasa dengan menunjuk secara langsung penyedia jasa yang memenuhi kriteria dan berpengalaman dibidangnya. Pekerjaan yang termasuk dalam sistem Penunjukan Langsung yaitu pekerjaan yang nilainya dibawah Rp 200.000.000,- . SKPD akan memilih penyedia jasa yang telah terdaftar pada asosiasi, dan tentunya memiliki pengalaman dan kompetensi sesuai bidangnya. SKPD yang menjalankan sistem Penunjukan Langsung membentuk tim untuk memilih penyedia jasa. Tim pada Penunjukan Langsung ini yaitu dimulai dengan Kuasa Pengguna Anggaran (KPA) menyetujui pengadaan tersebut dan memerintahkan pejabat pembuat komitmen (PPKOM) untuk memproses pengadaan barang/jasa, kemudian PPKOM memerintahkan Pejabat Pengadaan untuk melakukan proses pengadaan barang dan jasa. Pejabat Pengadaan memilih penyedia barang yang akan menyediakan barang dan jasa yang diminta oleh unit sampai dengan transaksi. Penyedia jasa di tunjuk oleh Pengguna Anggaran (PA) biasanya oleh Kepala Dinas atau Camat kemudian menunjuk siapa saja yang setingkat dibawahnya yang dirasa mampu menjalankan Penunjukan Langsung.

\section{Customer Relationship Manajement (CRM)}

Customer Relationship Management adalah suatu alat yang dapat membantu organisasi mencapai sasarannya tetap menerapkan konsep-konsep dan teknologiteknologi CRM terhadap suatu operasi bisnis, bergantung kepada jenis-jenis bisnis 
dan seberapa jauh ingin menerapkan CRM dan manajemen harus meneliti masalahmasalah yang mungkin ditemukan selama proses, sebelum dan sesudah melaksanakan penerapan CRM tersebut. Akan tetapi tidak semua organisasi yang melaksanakan CRM itu berhasil. Untuk memperoleh implementasi CRM yang berhasil organisasi-organisasi hendaknya mengevaluasi bagaimana CRM itu sesuai dengan seluruh strategi bisnis mereka seutuhnya, mengevaluasi kapasitas-kapasitas CRM nya dan mempunyai alasan bisnis untuk menerapkan CRM. Pembagian CRM kedalam tiga komponen pada Penunjukan Langsung penyedia jasa konstruksi :

1. Manusia

Mengelola hubungan diperlukan personal touch, maka manusia menjadi faktor utama dalam CRM. Untuk mendapatkan proyek Penunjukan Langsung diperlukan hubungan relasi yang perlu dibangun oleh pihak penyedia jasa dengan pihak SKPD pemberi kerja. Dari hasil wawancara dengan owner CV. Dwi Cahya Perkasa, pembagian tugas dilakukan dalam perusahaannya. Staff bertugas untuk mencari atau membuka web SIRUP untuk mencari informasi tentang jenis-jenis pekerjaan yang termasuk dalam Penunjukan Langsung, sedangkan yang bertugas mencari informasi tentang pelanggan dan mengelola hubungan atau relasi dilakukan oleh owner CV. Dwi Cahya Perkasa sendiri. Owner CV. Dwi Cahya Perkasa mengelola hubungan atau relasi untuk mendapatkan pekerjaan Penunjukan Langsung dengan kepala SKPD dan Kepala Seksi bagian Pembangunan.

Dari hasil wawancara dengan pihak pesaing ditemukan dalam sistem Penunjukan Langsung perlu terjalin hubungan baik antara penyedia jasa dengan pejabat yang berwenang. Adanya hubungan baik ini supaya tidak hanya mendapatkan proyek pada saat ini saja tetapi bisa berkelanjutan.

2. Proses

Proses dalam sistem Penunjukan Langsung yang harus dilakukan oleh CV. Dwi Cahya Perkasa sebagai penyedia jasa untuk mendapatkan pekerjaan yaitu yang pertama dengan membuka web SIRUP (Sistem Informasi Rencana Usulan Pengadaan), kemudian penyedia jasa membuat surat permohonan pekerjaan dengan dilampiri Company Profile perusahaan sebagai bahan pertimbangan dan menjelaskan pengalaman pekerjaan yang disampaikan langsung kepada Pejabat Pengadaan pada SKPD yang dituju. Pernyataan owner ini juga sesuai dengan pola hasil wawancara dengan pihak pesaing yaitu untuk mendapatkan proyek melalui Penunjukan Langsung dimulai dari penyedia jasa mengajukan permohonan pekerjaan dan Company Profile yang ditujukan kepada SKPD yang bersangkutan.

3. Tekhnologi

Teknologi digunakan untuk lebih membantu mempercepat dan mengoptimalkan faktor manusia dan proses dalam aktivitas Customer Relationship Management (CRM). Pada proses mendapatkan proyek Penunjukan Langsung, Pemerintah telah menggunakan teknologi yaitu berbasis web yang diberi nama SIRUP kepanjangan dari Sistem Informasi Rencana 
Umum Pengadaan. SKPD yang memiliki proyek Penunjukan Langsung dapat memposting rencana pekerjaan kedalam web SIRUP, kemudian penyedia jasa dapat mengakses web SIRUP untuk melihat SKPD mana saja yang memiliki pekerjaan Penunjukan Langsung dan jenis pekerjaannya. Hasil wawancara dengan owner CV. Dwi Cahya Perkasa, teknologi yang digunakan untuk mengelola hubungan atau relasi hanya menggunakan alat komunikasi seperti handphone melalui whatsapp dan telphone. Mengelola hubungan atau relasi lebih intens dilakukan secara tatap muka dengan mengunjungi kantor SKPD.

\section{Kualitas Pelayanan}

1. Kepercayaan

Dari hasil wawancara dengan pihak SKPD ditemukan bahwa penunjukan langsung kepada CV. Dwi Cahya Perkasa karena dianggap mampu untuk mengerjakan pekerjaan Penunjukan Langsung. Penyedia jasa yang memiliki tanggung jawab atas pekerjaannya yang telah diberikan oleh pihak SKPD juga menjadi alasan mengapa SKPD menunjuk penyedia jasa tersebut. Untuk mengetahui penyedia jasa tersebut mampu dan bertanggungjawab maka diperlukan hubungan relasi dan menjalin komunikasi, sehingga timbul rasa percaya dari pihak SKPD terhadap penyedia jasa yang akan di tunjuk.

Hasil wawancara dengan owner CV. Dwi Cahya Perkasa dalam meningkatkan kepercayaan pihak SKPD sebagai pelanggan dengan cara selalu menjalin komunikasi sebelum mendapatkan pekerjaan, pada saat melaksanakan pekerjaan hingga selesai pekerjaan, karena komunikasi dianggap penting oleh owner. Komunikasi menjadi salah satu kunci untuk membangun hubungan relasi sehingga timbul rasa percaya antara kedua belah pihak yaitu SKPD dan Penyedia Jasa konstruksi.

2. Kualitas Produk

Dari pola hasil wawancara dengan pihak SKPD ditemukan bahwa produk yang dihasilkan oleh CV. Dwi Cahya Perkasa selama mengerjakan pekerjaan Penunjukan Langsung hasilnya baik. Pekerjaan sesuai dengan spesifikasi pada Surat Perintah Kerja (SPK), serta dapat diterima oleh pihak SKPD. CV. Dwi Cahya Perkasa menjaga kualitas produknya dengan meggunakan bahan yang sesuai standart yang telah ditentukan dalam kontrak kerja serta menyelesaikan pekerjaan tepat waktu.

3. Jaminan

Dari hasil wawancara dengan pihak SKPD, pesaing dan owner CV. Dwi Cahya Perkasa ditemukan bahwa hasil pekerjaan dari proyek Penunjukan Langsung terdapat jaminan yaitu jaminan pemeliharaan. Jaminan pemiliharaan sebagai tanggung jawab penyedia jasa setelah pekerjaan selesai pada masa pemeliharaan yang telah ditentukan.

4. Empati

Dari hasil wawancara dengan pihak owner CV. Dwi Cahya Perkasa, staf atau pelaksana dilapangan selalu diberikan pengetahuan untuk melaksanakan pekerjaan sesuai dengan yang tercantum pada kontrak kerja. Pemahaman atas kebutuhan pelanggan atau pihak SKPD apabila pihak SKPD meminta pekerjaan 
yang tidak terdapat pada kontrak kerja maka staff lapangan dapat menolak dan tidak harus dikerjakan apabila nilainya dianggap terlalu besar.

5. Daya Tanggap

Kesedian untuk membantu para pelanggan dan memberikan dengan tanggap pada CV. Dwi Cahya Perkasa dilakukan dengan ikut membantu proses pengadaan antara lain proses perencanaan dan memberikan masukan apabila dalam perencanaan pekerjaan kurang tepat. Bantuan ini diberikan biasanya untuk SKPD non-teknis dan tidak memiliki sumber daya manusia (SDM) yang menguasi dalam bidang konstruksi.

\section{Kepuasan Pelanggan}

1. Kualitas Produk

Pelanggan akan puas apabila evaluasi hasil setelah membeli dan menggunakan produk tersebut, ternyata produk yang digunakan berkualitas baik. Dari pola hasil wawancara dengan pihak SKPD kualitas produk menjadi penilaian utama pada proyek Penunjukan Langsung. Produk yang dihasilkan pada proyek Penunjukan Langsung adalah produk yang kasat mata sehingga dapat dilihat dan dirasakan kualitasnya. Kualitas produk yang dihasilkan oleh penyedia jasa dianggap baik apabila hasilnya sesuai dengan spesifikasi yang terdapat pada Surat Perintah Kerja (SPK). Meningkatkan mutu produk yang dihasilkan merupakan salah satu usaha untuk menjada kualitas hasil pekerjaan yang dilakukan oleh penyedia jasa agar pihak SKPD sebagai pelanggan selalu merasa puas.

2. Kualitas Pelayanan

Pelayanan yang sesuai dengan yang diharapkan oleh konsume akan memberikan rasa puas terhadap konsumen. Dari pola hasil wawancara dengan pihak SKPD kepuasan pelanggan diukur dengan hasil pekerjaan yang sesuai dengan Surat Perintah Kerja (SPK) dan juga hasil pekerjaan secara fisik yang dilihat dari pemeriksaan dilapangan.

\section{Kaitan antara Customer Relationship Management dengan Kualitas Pelayanan}

Customer relationship management (CRM) yang dilakukan oleh penyedia jasa untuk mendapatkan proyek Penunjukan Langsung dengan mengikuti prosedur Penunjukan Langsung dan menjalin komunikasi dengan kepala SKPD. Setelah dipercaya untuk mengerjakan proyek Penunjukan Langsung, penyedia jasa memberikan pelayanan yang berkualitas untuk SKPD. Pelayanan yang berkualitas pada proyek Penunjukan Langsung diberikan melalui proses pengerjakan proyek tersebut.

Penyedia jasa menggunakan bahan yang sesuai dengan standart yang telah ditentukan pada kontrak kerja dan menggunakan peralatan yang memadai. Sehingga hasil dari pekerjaan Penunjukan Langsung memiliki kualitas yang baik dan sesuai dengan spesifikasi. Komunikasi antara penyedia jasa dengan SKPD juga terus dibangun selama proses pekerjaan Penunjukan Langsung agar hasil pekerjaan sesuai yang diinginkan dan tidak ada kesalahan. Setelah pekerjaan selesai penyedia jasa 
juga memberikan jaminan pemeliharaan untuk hasil pekerjaannya, ini sebagai salah satu layanan yang diberikan oleh penyedia jasa.

SKPD menunjuk penyedia jasa dengan melihat kemampuan penyedia jasa untuk mengerjakan pekerjaan, tanggung jawab dan kualitas pekerjaan yang dihasilkan. Maka antara customer relationship management dengan kualitas pelayanan pada proyek Penunjukan Langsung ini memiliki kaitan yaitu setelah penyedia jasa membangun hubungan relasi maka pihak SKPD akan memberikan kepercayaan kepada penyedia jasa untuk mengerjakan proyek Penunjukan Langsung. SKPD memilih penyedia jasa yang memiliki pengalaman di bidangnya. Setelah mendapatkan proyek Penunjukan Langsung, penyedia jasa harus memberikan pelayanan yang berkualitas untuk mempertahankan kepercayaan SKPD.

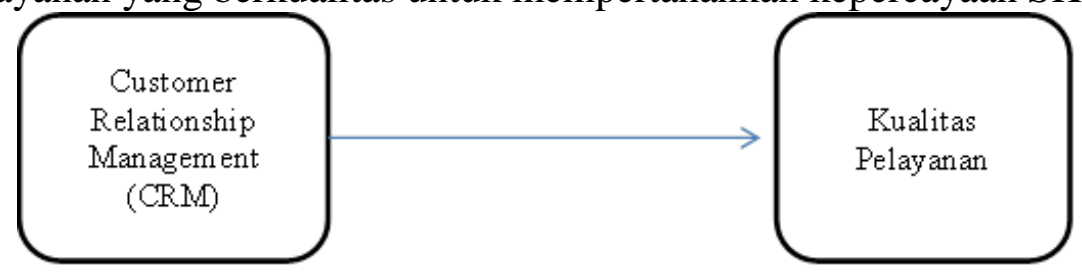

Gambar 1

Perusahaan yang menerapkan customer relationship management (CRM) akan memberikan pelayanan yang berkualitas untuk melayani pelanggannya.

\section{Kaitan antara Customer Relationship Management (CRM) dengan Kepuasan Pelanggan}

Pada proyek Penunjukan Langsung, strategi yang digunakan penyedia jasa untuk mendapatkan proyek yaitu melalui strategi customer relationship management (CRM) dengan membangun hubungan baik antara penyedia jasa dengan kepala SKPD. Tujuan dari membangun hubungan baik ini untuk mendapatkan proyek Penunjukan Langsung tidak hanya saat ini saja namun berkelanjutan. Hubungan relasi yang baik dan berkelanjutan dapat diwujudkan melalui adanya kepuasan dari pelanggan terhadap hasil pekerjaan.

Keseluruhan kegiatan yang dilakukan oleh sebuah perusahaan, pada akhirnya akan bermuara pada nilai yang akan diberikan oleh konsumen mengenai kepuasan yang dirasakan. Kaitan antara customer relationship management (CRM) dengan kepuasan pelanggan pada proyek Penunjukan Langsung yaitu SKPD merasa puas apabila hasil dari pekerjaan sesuai dengan spesifikasi pada kontrak kerja. Pekerjaan selesai tepat pada waktunya sesuai yang telah ditentukan dan hasilnya pun baik. Pada saat pemeriksaan hasil pekerjaan tidak ada temuan oleh tim pemeriksa. Untuk meningkatkan kepuasan SKPD, penyedia jasa terus meningkatkan mutu hasil pekerjaannya, serta meningkatkan daya tanggap akan kebutuhan SKPD.

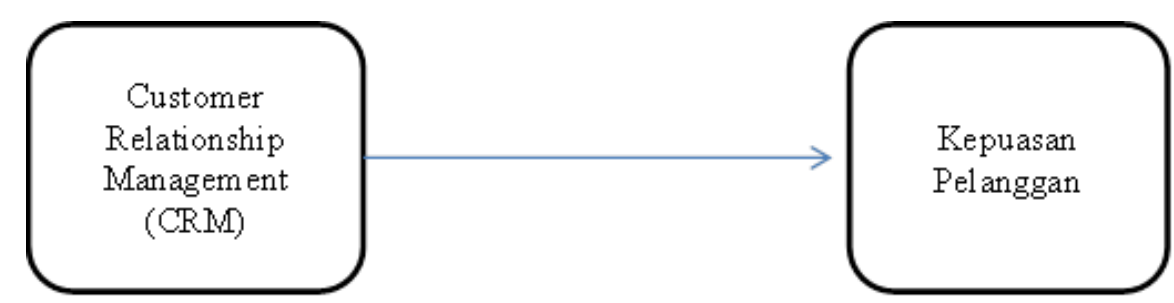


Gambar 2

Penerapan customer relationship management (CRM) yang baik oleh sebuah perusahaan kepada pelanggannya, akan mempengaruhi kepuasan yang dirasakan oleh pelanggannya

\section{Kaitan antara Kualitas Pelayanan dan Kepuasan Pelanggan}

Kaitan kualitas pelayanan dengan kepuasan pelanggan pada Penunjukan Langsung yaitu kualitas pelayanan dari penyedia jasa pada proyek Penunjukan Langsung diberikan melalui penggunaan bahan yang berkualitas serta peralatan yang memadai, sehingga tercipta hasil pekerjaan yang berkualitas dan sesuai dengan spesfikasi pada kontrak kerja. Layanan prima juga diberikan kepada SKPD yang membutuhkan. Adanya jaminan pemeliharaan pada hasil pekerjaan yang telah selesai dan terus menjalin komunikasi selama pekerjaan berlangsung.

SKPD memilih penyedia jasa dengan melihat dari kemampuan penyedia jasa untuk mengerjakan pekerjaan, tanggung jawab dan kualitas hasil pekerjaan. Maka SKPD akan merasa puas apabila hasil pekerjaan dari penyedia jasa berkualitas dan sesuai dengan spesifikasi yang telah ditentukan. Sehingga pihak SKPD merasa tidak salah pilih menunjuk penyedia jasa.

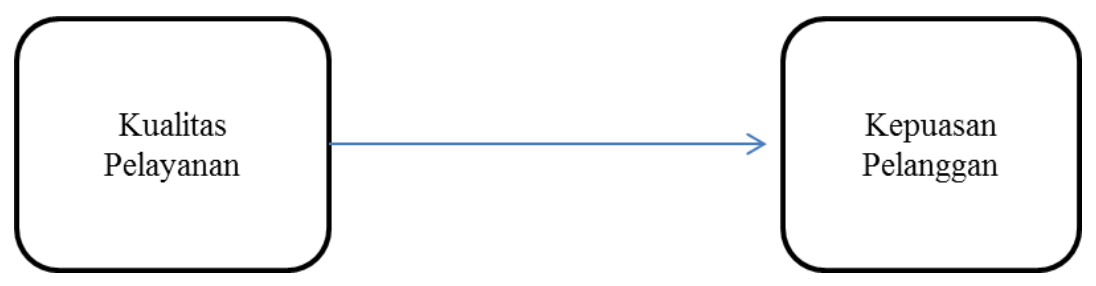

Gambar 3

Sebuah perusahaan yang memberikan pelayanan yang baik dan berkualitas serta sesuai dengan yang diharapkan oleh pelanggannya, akan meningkatkan nilai kepuasan yang dirasakan oleh pelanggannya.

\section{Bangunan Model Teori}

Berikut dibawah ini disajikan kaitan seluruh konsep tentang Customer Relationship Management (CRM), Kualitas pelayanan dan Kepuasan Pelanggan. 


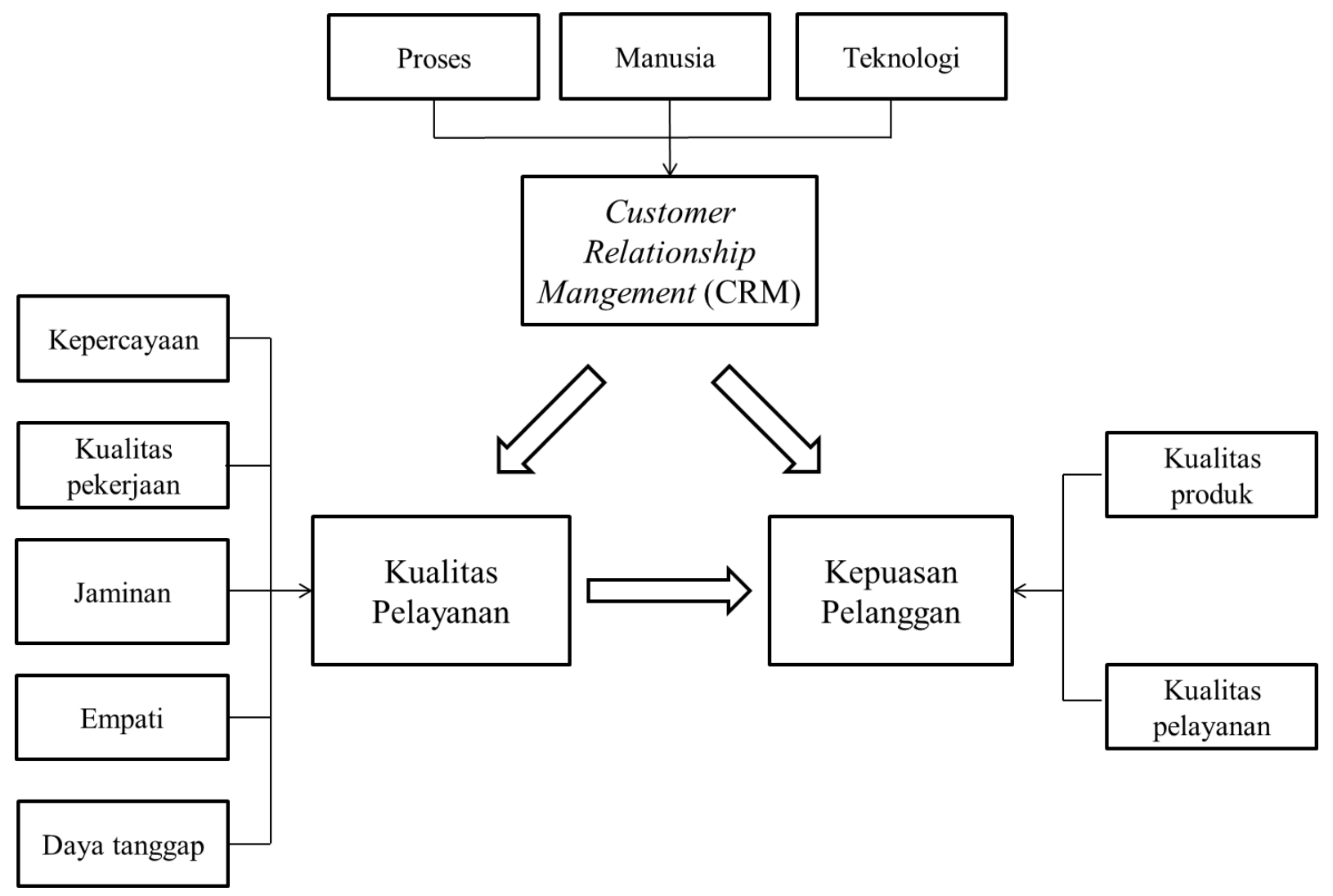

Gambar 4 Model Bangunan Teori 


\section{PENUTUP}

Dari hasil penelitian ini strategi untuk membangun hubungan baik penyedia jasa konstruksi dengan pelanggan untuk mendapatkan proyek konstruksi yaitu (1) penyedia jasa konstruksi yang menerapkan customer relationship management (CRM) untuk mendapatkan proyek penunjukan langsung berpengaruh terhadap kualitas pelayanan yang diberikan. Penyedia jasa konstruksi akan memberikan pelayan yang berkualitas juga untuk pelanggannya. (2) Penerapan customer relationship management (CRM) yang baik oleh penyedia jasa konstruksi akan mempengaruhi kepuasan pelanggan. (3) Sebuah perusahaan yang memberikan pelayanan yang baik dan berkualitas serta sesuai dengan yang diharapkan oleh pelanggannya, akan meningkatkan nilai kepuasan yang dirasakan oleh pelanggannya.

Penelitian ini telah diusahakan dan dilaksanakan sesuai dengan prosedur ilmiah demikian masih memiliki keterbatasan yaitu; (1) Penelitian ini menggunakan metode wawancara untuk mendapatkan informasi yang terkadang jawaban yang diberikan oleh subjek penelitian bersifat bias. Wawancara melalui tatap muka juga masih terdapat kesalahan bertanya dan juga menafsirkan jawaban; (2) Pertanyaan sering kali kurang baku. Sehingga sering menimbulkan persepsi yang berbeda. Bagian ini terdiri atas simpulan, implikasi manajerial dan keterbatasan dalam penelitian.

\section{DAFTAR PUSTAKA}

Aditia, I. (2012). Faktor-Faktor yang Mempengaruhi Kepuasan Pelanggan pada UD Pandan Wangi Semarang. Jurnal Kajian Akuntansi Dan Bisnis, 1(1).

Chadiq, U. (2015). Customer Relationship Management (CRM): Pilihan Strategi untuk Meraih Keunggulan Bersaing. Dharma Ekonomi, 18(33).

Darudiato, S., Novianto, C., Hendra, H., Reynaldo, R., \& Selvi, S. (2011). Membangun Customer Relationship Management dalam Bisnis. ComTech: Computer, Mathematics and Engineering Applications, 2(2), 1350-1358.

Kalalo, R. E. (2013). Customer relationship management dan kualitas pelayanan pengaruhnya terhadap loyalitas konsumen PT. Matahari Dept. Store, Manado. Jurnal EMBA: Jurnal Riset Ekonomi, Manajemen, Bisnis Dan Akuntansi, 1(4).

Lukas, A. (2001). Customer Relationship Management, CRM Slide Pesentation. Jakarta: Ciptamaya.

Rizan, M., \& Arrasyid, H. (2008). Analisis Asosiasi Merek, Nilai Produk, dan Kualitas Pelayanan, Serta Pengaruhnya Terhadap Kepuasan Dan Loyalitas Konsumen Sepeda Motor di Bekasi. Jurnal Fakultas Hukum UII, 12(2).

Wildyaksanjani, J. P., \& Sugiana, D. (2018a). Strategi Customer Relationship Management (CRM) PT Angkasa Pura II (Persero). Jurnal Kajian Komunikasi, 6(1), 10-23. 